Discussion Paper No. 12-035

Concrete Shoes for Competition The Effect of the German Cement Cartel on Market Price

Kai Hüschelrath, Kathrin Müller and Tobias Veith

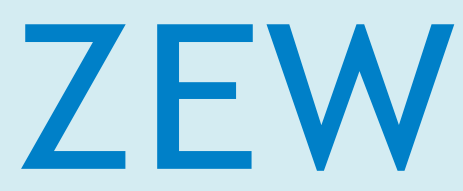

Zentrum für Europäische Wirtschaftsforschung $\mathrm{GmbH}$ Centre for European Economic Research 
Discussion Paper No. 12-035

\title{
Concrete Shoes for Competition The Effect of the German Cement Cartel on Market Price
}

\author{
Kai Hüschelrath, Kathrin Müller and Tobias Veith
}

Download this ZEW Discussion Paper from our ftp server:

http://ftp.zew.de/pub/zew-docs/dp/dp12035.pdf

Die Discussion Papers dienen einer möglichst schnellen Verbreitung von neueren Forschungsarbeiten des ZEW. Die Beiträge liegen in alleiniger Verantwortung der Autoren und stellen nicht notwendigerweise die Meinung des ZEW dar.

Discussion Papers are intended to make results of ZEW research promptly available to other economists in order to encourage discussion and suggestions for revisions. The authors are solely responsible for the contents which do not necessarily represent the opinion of the ZEW. 


\section{Non-technical summary}

Since 2004, the European Commission (EC) has taken a number of steps to develop a legal framework that allows victims of EU antitrust infringements to obtain compensation. In its Green Paper on damages actions for breach of antitrust rules, the EC (2005) concluded that the robust quantification of the caused damage is one of the key barriers to a further promotion of antitrust damages actions. Consequently, in the subsequent White Paper published in 2008 - the EC announced the plan to derive a coherent economic framework which provides pragmatic, non-binding guidance on the quantification of harm. A first draft of this Guidance Paper was published in June 2011.

Although the public and academic discourse on the various methods and models to estimate damages certainly is a necessary step in the process of strengthening antitrust damages actions, the challenges of applying them in actual cases with real-world data are often ignored. Given the fact that the final damage value basically is a function of the demanded quantities of the cartelized product and the cartel-induced increase in price, it becomes apparent that especially the robust estimation of the so-called price overcharge is crucial for a coherent and welfare-improving private enforcement of anti-cartel rules.

Against this background, we use publicly available price data from a German cement cartel to estimate the achieved price overcharge. In particular, we apply two different comparatorbased approaches - a 'before-and-after' approach and a 'difference-in-differences' approach and especially study the impact of various assumptions on the transition period from the cartel period to the non-cartel period on the estimated price overcharge. We find that the cartel managed to implement price increases in a range from $20.3 \%$ (extended approach with instrumented cement demand) to $20.7 \%$ (basic approach) for the 'before-and-after' method and from $26.2 \%$ (pooled OLS) to $26.5 \%$ (random-effects) for the 'difference-in-differences' method. For the (extended) 'before-and-after' approach, we further show that various assumptions on the transition period from the cartel period to the non-cartel period have a significant impact on the estimated price overcharge. 


\section{Das Wichtigste in Kürze}

Seit dem Jahr 2004 hat die Europäische Kommission eine Reihe von Schritten unternommen, einen rechtlichen Rahmen zu entwickeln, der es durch Wettbewerbsverstöße geschädigten Parteien erlaubt, eine entsprechende Kompensation zu erhalten. So veröffentlichte die Kommission beispielsweise im Jahr 2005 ein Grünbuch zur privatrechtlichen Durchsetzung des Kartellrechts, in dem sie insbesondere die vielfältigen Probleme einer Quantifizierung des entstehenden Schadens als eine große Hürde in der Umsetzung identifizierte. Im sich anschließenden Weißbuch aus dem Jahre 2008 kündigte die Kommission dann die Entwicklung von umfassenden aber unverbindlichen Richtlinien zur Schadensermittlung an. Ein erster Entwurf dieser Richtlinien wurde im Juni 2011 publiziert.

Obwohl die aktuell stattfindende öffentliche wie wissenschaftliche Diskussion der verschiedenen Methoden und Modelle der Schadensermittlung ein wichtiger und notwendiger Schritt zur Stärkung der privatrechtlichen Durchsetzung des Kartellrechts ist, kommt die Würdigung der Herausforderungen einer praktischen Umsetzung der entsprechenden Methoden oftmals zu kurz. Da die finale Schadenssumme sowohl von den nachgefragten Mengen des Kartellgutes als auch dem kartellinduzierten Anstieg der Marktpreise abhängt, wird insbesondere die Bedeutung einer robusten Schätzung des sogenannten kartellbedingten Preisaufschlags für eine schlüssige und wohlfahrtserhöhende privatrechtliche Durchsetzung des Kartellverbots unmittelbar deutlich.

Vor diesem Hintergrund nutzen wir öffentlich verfügbare Daten zu einem deutschen Zementkartell für eine Abschätzung des vom Kartell durchgesetzten Preisaufschlags. Konkret wenden wir zwei unterschiedliche komparatorenbasierte Schätzverfahren an - die Methode des zeitlichen Vergleichsmarkts und die ,Difference-in-differences'-Methode - und untersuchen insbesondere den Einfluss verschiedener Annahmen im Hinblick auf die Übergangsperiode von der Kartellabsprache zum Wettbewerb auf die Höhe des Preisaufschlags. Unsere Schätzungen ergeben einen Preisaufschlag zwischen 20,3 Prozent (erweitertes Modell mit instrumentierter Zementnachfrage) und 20,7 Prozent (Basismodell) für die Methode des zeitlichen Vergleichsmarkts und zwischen 26,2 Prozent (,pooled OLS') und 26,5 Prozent (,Random Effects') für die ,Difference-in-differences'-Methode. Für das erweiterte Modell des zeitlichen Vergleichsmarkts zeigen wir ferner, dass verschiedene Annahmen zur Übergangsperiode vom Kartell- zum Nicht-Kartellzeitraum einen signifikanten Einfluss auf den geschätzten Preisaufschlag haben. 


\title{
CONCRETE SHOES FOR COMPETITION THE EFFECT OF THE GERMAN CEMENT CARTEL ON MARKET PRICE
}

\author{
Kai Hüschelrath*, Kathrin Müller* and Tobias Veith*
}

May 2012

\begin{abstract}
We use publicly available price data from the German cement industry to estimate the cartelinduced price increase. We apply two different comparator-based approaches - the 'beforeand-after' approach and the 'difference-in-differences' approach - and especially study the impact of various assumptions on the transition period from the cartel period to the non-cartel period on the overcharge estimate. We find that the cement cartel led to price overcharges in a range from 20.3 to 26.5 percent depending on model approach and model assumptions.
\end{abstract}

Keywords Antitrust policy, cartels, private enforcement, damages, overcharge

JEL Class L41, L61, K21

\footnotetext{
* Head, Competition and Regulation Research Group, ZEW Centre for European Economic Research, P.O. Box 1034 43, D-68034 Mannheim, Germany, E-mail: hueschelrath@zew.de; Coordinator, MaCCI Mannheim Centre for Competition and Innovation; Assistant Professor for Industrial Organization and Competitive Strategy, WHU Otto Beisheim School of Management, Burgplatz 2, 56179 Vallendar, Germany. Parts of the paper refer to a study on cartel damage estimations which was financially supported by Cartel Damage Claims (CDC), Brussels. The study is published in German language (see Hüschelrath et al., 2012). We are especially indebted to Jakob Rüggeberg (CDC) for valuable comments on previous versions of the paper.

* Researcher, Competition and Regulation Research Group, ZEW Centre for European Economic Research and MaCCI Mannheim Centre for Competition and Innovation, P.O. Box 1034 43, D-68034 Mannheim, Germany, E-mail: kathrin.mueller@zew.de.

* Researcher, Department for Industrial Economics and International Management, ZEW Centre for European Economic Research, P.O. Box 1034 43, 68034 Mannheim, Germany, E-mail: veith@zew.de.
} 


\section{Introduction}

The desire of firms to ease competitive pressures and increase joint profits through the implementation of cartel agreements has long been recognized by academics. Although Adam Smith's (1776) famous statement on the social harmfulness of (price) coordination among competitors is usually seen as the foundation of a large literature on the economics of cartel agreements, the general concept of cartelization and the need for state intervention is already expressed quite clearly in manuscripts of Greek philosophers such as Aristotle ${ }^{1}$ (347 BC).

In the modern industrial organization literature, a hardcore cartel is typically defined as “... a group of firms who have agreed explicitly among themselves to coordinate their activities in order to raise market price - that is, they have entered into some form of price fixing agreement" (Pepall et al., 2001), p. 345). A perfectly functioning hardcore cartel involving all firms in the market and referring to substitutive products - is expected to raise market price up to the monopoly level thereby harming overall and consumer welfare substantially. As hardcore cartels usually do not create any kind of benefits to society which could be traded-off against the anticompetitive effects, hardcore cartels are a prime example for a per se prohibition reflected in many antitrust legislations around the world.

An answer to the subsequent question after the design of an antitrust enforcement system for anti-cartel rules must refer to two different strands: public enforcement and private enforcement. Public enforcement basically means that antitrust rules are enforced by state authorities. Through the imposition of a threat of civil, administrative or criminal sanctions for violations of the respective laws and regulations, policy makers aim to alter the costbenefit assessment for forms of anticompetitive behavior on the firm's side sufficiently to make compliance the dominant strategy.

By contrast, private enforcement is based on the actions of private parties - such as competitors, suppliers, customers or consumers - who can bring antitrust lawsuits based on the private damages caused by forms of anticompetitive behavior. Since 2004, the European Commission (EC) has taken a number of steps to develop a legal framework that allows victims of EU antitrust infringements to obtain compensation. In its Green Paper on damages actions for breach of antitrust rules, the EC (2005) concluded that the robust quantification of the caused damage is one of the key barriers to a further promotion of antitrust damages actions. Consequently, in the subsequent White Paper - published in 2008 - the EC announced the plan to derive a coherent economic framework which provides pragmatic, non-

\footnotetext{
Aristotle, Politica (347 BC), Part XI.
} 
binding guidance on the quantification of harm. A first draft of this Guidance Paper was published in June 2011.

Although the public and academic discourse on the various methods and models to estimate damages certainly is a necessary step in the process of strengthening antitrust damages actions, the challenges of applying them in actual cases with real-world data are often ignored. Given the fact that the final damage value basically is a function of the demanded quantities of the cartelized product and the cartel-induced increase in price, it becomes apparent that especially the robust estimation of the so-called price overcharge is crucial for a coherent and welfare-improving private enforcement of anti-cartel rules.

Against this background, we use publicly available price data from the German cement industry to estimate the achieved cartel price overcharge. In particular, we apply two different comparator-based approaches - a 'before-and-after' approach and a 'difference-indifferences' approach - and especially study the impact of various assumptions on the transition period from the cartel period to the non-cartel period on the estimated price overcharge. We find that the cartel managed to implement price increases in a range from 20.3 to 26.5 percent depending on model approach and model assumptions.

The paper is structured as follows. In the subsequent second section, we present a brief review of existing research on the estimation of price overcharges realized by hardcore cartels. We differentiate between a characterization of key empirical approaches and existing empirical evidence on the sizes of price overcharges. As an important precondition for a robust econometric analysis of the price overcharge is a profound understanding of both the respective market in general and the cartel agreement in particular, the third section concentrates on, first, an overview of the key economic characteristics of the cement market, and, second, a characterization of the latest German cement cartel. In the fourth section, we use publicly available price data to estimate the price overcharge of the German cement cartel. Section 5 concludes the paper with a summary of its key results and a discussion of further research needs.

\section{Estimation of price overcharges - A review of the literature}

In this section, we present a brief review of existing research on the estimation of price overcharges of hardcore cartels. We differentiate between a characterization of key empirical approaches and existing empirical evidence on the sizes of price overcharges. 


\subsection{Empirical approaches}

Economic research has developed several classifications of methods to estimate price overcharges (see, e.g., van Dijk und Verboven, 2008; CEPS et al., 2007 and Oxera, 2009). For example, the seminal contribution by Oxera (2009) differentiates between three broad groups of methods: comparator-based, financial-performance-based, and market-structure-based. Comparator-based approaches use external data to estimate the price overcharge by a) crosssectional comparisons (comparing different geographic or product markets); b) time-series comparisons (analyzing prices before, during and/or after an infringement); and c) combining approaches a) and b) in a so-called 'difference-in-differences' model (e.g., analyzing the change in price for a cartelized market over time, and comparing this change against the change in price in a non-cartelized market over the same time period).

Financial-analysis-based approaches use financial information on comparator firms and industries, benchmarks for rates of return, and cost information on defendants and claimants to estimate the counterfactual. Examples for techniques in this category are the examination of financial performance such as profitability or bottom-up costing of the cartelized product to derive the 'but-for' price.

Market-structure-based approaches use a combination of theoretical models and empirical estimations to simulate a counterfactual estimate. Applying such an approach demands in a first step the identification of a theoretical model that fits best to the 'relevant' market (e.g., a Cournot oligopoly model or a Bertrand price competition model). Such a theoretical model helps in understanding how competition works in the respective market and how a reasonable 'but-for' price should look like. In a second step, the respective model can be calibrated using standard econometric techniques.

The different methods to estimate 'but-for' prices differ significantly with respect to their input requirements, conceptual complexity, technical complexity and underlying assumptions. Given these differences and the diverse characteristics of real-world cartels, Oxera (2008) among others argues that there is no one-size-fits-all approach. To the contrary, it is not only necessary to identify the most suitable methods on a case-by-case basis. But it is also advisable to apply several methods in parallel in order to cross-check (or even pool) the results to arrive at a robust and reliable estimate of the 'but-for'-price. In the following, we will characterize two empirical approaches out of the group of comparator-based tools in greater detail: the 'before-and-after' approach and the 'difference-in-differences' approach. 


\subsection{1 ,Before-and-after` approach}

The before-and-after approach basically compares the price during the cartel period with the price in the same market before and/or after the cartel period. On the one hand, the approach can be implemented by simply comparing the average prices between these periods. Alternatively, the price overcharge can be estimated by multivariate models that take relevant control variables into account. Multivariate models have the key advantage that they allow the inclusion of other determinants of the price in the cartel and non-cartel periods such as seasonal effects or technological changes (see, e.g., Connor, 2008).

Technically, a multivariate comparison of the cartel period with the non-cartel period can be implemented by two distinct approaches. The 'dummy variable' approach introduces an indicator variable for the cartel period. This variable has a value of ' 1 ' during the cartel period and a ' 0 ' otherwise. The impact of this variable on price represents the cartel overcharge. The 'price prediction' approach, however, predicts the prices in the cartel period on the basis of the prices in the non-cartel period given the change in market, companies and other characteristics in the cartel period. Depending on data availability, the prices before or after the cartel might be used to estimate the 'but-for' price. Ideally, both possibilities are executed and therefore allow conclusions on the robustness of the results (see Nieberding, 2006).

The 'before-and-after' method has certain key advantages that explain its frequent application in overcharge estimations. First, data requirements are limited to time series of the respected cartelized product. Second, the economic concept behind the approach is quite straightforward thereby easing its application in court proceedings. Third, an estimation of the overcharge is technically relatively easy to implement and therefore suitable for implementation in a relatively short time window for the analysis. Fourth, it is not necessary to make any assumptions on industry conduct absent the cartel.

These various advantages of the method have to be traded off against several potential disadvantages or challenges. In general, the performance of the ,before-and-after' approach depends on the degree to which prices before/after the cartel provide a good approximation of the competitive prices in the long-run equilibrium. It is therefore crucial to closely investigate industry and market conditions before and after the cartel (see ABA, 2010). If the post-cartel period is chosen as comparator, overcharges might on the one hand be underestimated due to a possible continuation of (possibly tacit) collusion among the former cartel members (see, e.g., Harrington, 2004a, 2004b). On the other hand, an overestimation is possible if the former cartel members reduce prices below the competitive level, either to calm down angry 
customers (see Connor, 2008), or due to a price war that follows the breakdown of the cartel (see de Coninck, 2010).

Due to the identified potential problems of the post-cartel period as comparator, van Dijk and Verboven (2008) among others propose to use the pre-cartel period as comparator. However, in addition to possible difficulties with respect to data availability, the pre-cartel period might also be special in the sense that, e.g., a recession took place that increased the desire among firms to form a cartel or a cartel was formed to end a period of 'ruinous' price competition in the industry (see, e.g., Brander und Ross, 2006). In both cases, the pre-cartel period would be a problematic reference period to derive the competitive market price. Last but not least, it is important to note that the derivation of the exact cartel period is not necessarily straightforward (see Friederiszick und Röller, 2010). As cartels typically do not collapse from one point in time to the other (e.g., due to long-term contractual relationships), the cartel duration identified as part of public enforcement might diverge from the cartel duration relevant for private enforcement (see, e.g., Brander and Ross, 2006; Verboven, 2007). Ignoring the transition period from the cartel state to the non-cartel state is likely to lead to an inexact estimation of the price overcharge of the cartel.

\subsection{2 ,Difference-in-Differences' ${ }^{*}$ approach}

The ,difference-in-differences' (DiD) approach evaluates price developments at different points in time across different markets. The technique is therefore able to isolate the price effects of the cartel from both a time perspective and a geographic or product market perspective (see, e.g., Verboven, 2007).

In principle, the DiD approach can be applied either qualitatively by simple comparisons of the average prices in markets with/without cartel presence or quantitatively by estimating the price overcharge through a multivariate regression approach. Table 1 shows the application of a DiD approach based on a simple comparison of average prices.

Table 1: Example of a ,difference-in-differences‘ model

\begin{tabular}{l|c|c|c}
\hline & $\begin{array}{c}\text { Before-Cartel } \\
\text { period }\end{array}$ & Cartel Period & Damage estimate \\
\hline Cartelized Market & A & B & \multirow{2}{*}{ (B-A)-(D-C) } \\
\hline $\begin{array}{l}\text { Non-Cartelized } \\
\text { Market }\end{array}$ & C & D & \\
\hline
\end{tabular}

Source: largely following Oxera (2009), p. 61. 
The technique uses the average price on the cartelized market in the pre-cartel period (A) and the corresponding average prices for the cartelized market in the cartel period (B), the noncartelized market before the cartel (C) and the non-cartelized market in the cartel period (D). The difference (B-A) measures the change in the average price from the pre-cartel to the cartel period in the cartelized market while difference (D-C) shows the change in the average price on the comparator market. Although at first glance, one might think that the difference (B-A) is equal to the price overcharge of the cartel, a second look reveals that not necessarily the entire price difference (B-A) must be caused by the cartel agreement (e.g., because prices might have changed for other reasons such as cost changes during the cartel period). If the comparator market is most comparable to the cartelized market, the effect of these other drivers over time is expressed by (D-C) which must be lower than (B-A). Thus, the cartel effect in the cartelized market corresponds to the difference in the differences: (B-A)-(D-C).

Compared to the 'before-and-after' approach, the DiD model has substantially extended data requirements that often foreclose its application in practice. A key challenge in a meaningful application of the concept lies in the identification of a suitable comparator market, i.e., a market with similar demand, cost, and market structures. Ideally, these markets should neither be affected by (the same or other) cartels as well as other forms of anticompetitive behavior that might bias modeling results. However, as market characteristics for particular products are often similar in various countries, it is difficult to isolate a well suited comparator market for an application of a $\mathrm{DiD}$ approach.

\subsection{Empirical evidence}

Complementary to a characterization of empirical approaches to estimate the 'but-for' price, this section provides a brief overview of existing empirical evidence on the question 'how high do cartels raise price'? A substantial number of studies exist that derive such overcharge estimates for various cartels in various industries and countries. Connor and Lande (2006) present a survey paper in which they include average overcharges of six economic surveys consisting of (in sum) more than 100 cartels. They find that the average cartel overcharges differ considerably between the different empirical studies. Levenstein and Suslow (2004), for instance, calculate an average overcharge (mean) of 43\%, while Werden (2003) finds $21 \%$ (mean) and the OECD (2002) 15.75\% for the average overcharge (mean). The total average overcharge of all studies shows a mean of $30.7 \%$.

In a recent report, Oxera (2009) builds on a large data base of overcharges collected by Connor and Lande (2008) and further extends it to end up with more than 1000 observations on average overcharges from numerous cartels between 1780 and 2004. However, after 
excluding data base entries of cartels before 1960, entries for which an average estimate of the overcharge over the whole cartel period was unavailable, studies where the method for calculating the overcharge was not explicitly referred to and studies which were not published in peer-reviewed academic articles and chapters in published books, the sample size was reduced substantially to 114 . Figure 1 below shows the distribution of cartel overcharges of these 114 empirical studies of past cartels.

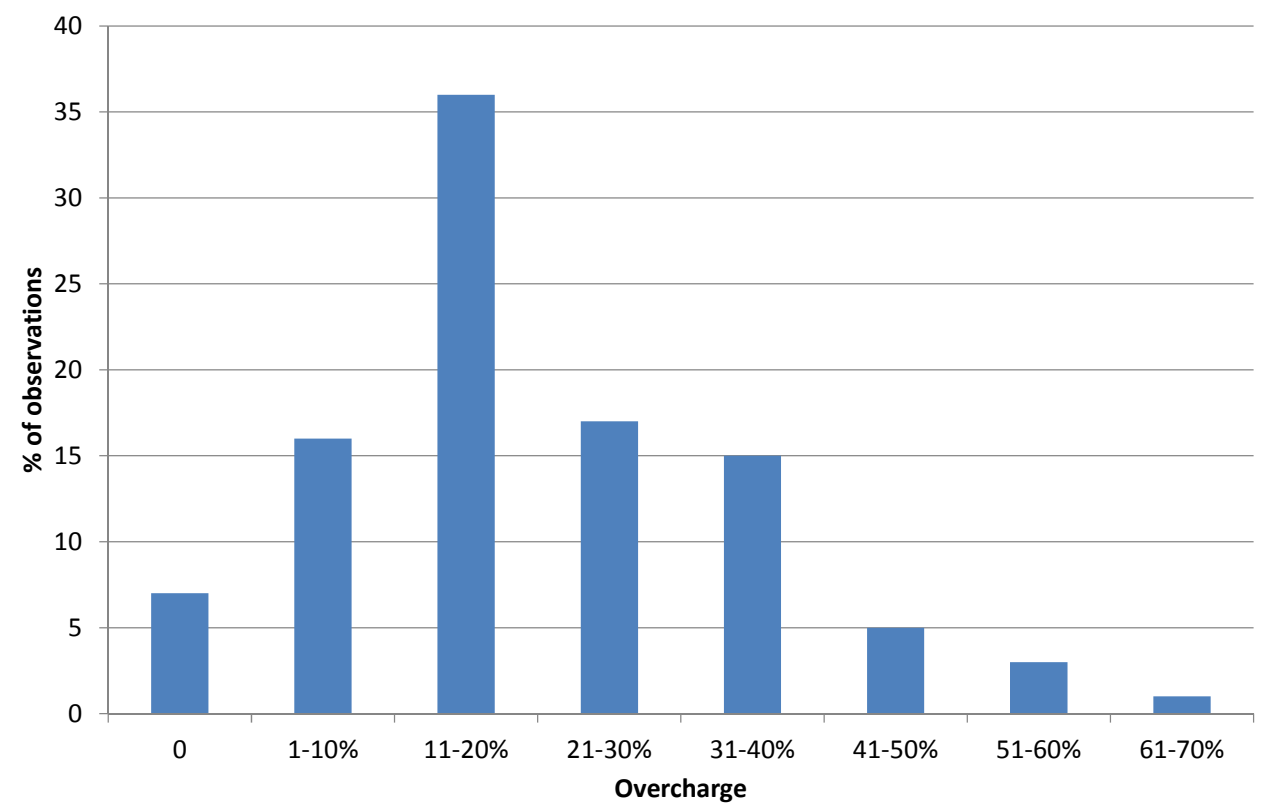

Figure 1: Distribution of cartel overcharges in empirical studies of past cartels Source: largely following Oxera (2009), p. 91.

As revealed by Figure 1, the range with the greatest number of observations is $11-20 \%$. According to Oxera (2009), the median overcharge is $18 \%$ of the cartel price while the (mean) average overcharge is found to be at around 20\%. However, it is important to note that the sample of cartel overcharges is quite heterogeneous along several dimensions. For example, it contains 52 international and 62 national cartels. Out of the sub-group of national cartels, only six European cartels (where cartels covered several European countries) and nine (singlecountry) European cartels are included leaving the large majority of national cartels referring to the United States or Canada. Interestingly, the North American cartels have a significantly smaller mean overcharge (16\%) than the six European cartels $(27 \%)$ in the data base. In general, the identified very limited evidence on the overcharges of particularly European cartels increases the relevance of our empirical analysis on the overcharge of a German cement cartel substantially. 


\section{The cement market and the German cement cartel}

An important precondition for a robust econometric analysis of the price overcharge of a hardcore cartel is a profound understanding of both the respective market in general and the cartel agreement in particular. As a consequence, this section concentrates on, first, an overview of the key economic characteristics of the cement market, and, second, a characterization of the latest German cement cartel.

\subsection{The cement market}

Cement can be broadly defined as a substance that sets and hardens independently, and can bind other materials together. Cement used in construction is largely so-called hydraulic cement that hardens when the anhydrous cement powder is mixed with water. Although cement is usually seen as a homogenous product, the current European standard EN 197-1 for common cements defines no less than 27 different cement types. However, a large fraction of the cement sales in most European countries refer to the so-called CEM I cement which contains only Portland cement clinker and no other possible constituents such as blast furnace slag, natural pozzolana, siliceous fly ash, burnt oil shale or limestone.

The cement production process can be subdivided into three main steps: the preparation of the raw mixture, the production of the clinker and the preparation of the cement. Cement producers tend to locate near the most important raw material source (which typically is lime). The production of the clinker through heating in a cement kiln is not only quite inflexible (in the sense that the costs per unit increase quickly with a reduction in capacity utilization) but is also particularly energy-intensive (which is why cement producers have started to (partly) replace clinker by other constituents during the final step of the preparation of the cement). In general, production characteristics suggest that high start-up costs are incurred with entry into the cement market, e.g. due to the necessary access to lime resources or the installation of production plants and mills.

The most common use for cement is in the production of concrete. Concrete is especially used in the construction industry either through the factory production of pre-cast units (such as panels, beams or road furniture), or through so-called 'cast-in-place' concrete needed for the construction of building superstructures, roads or dams. Given the seasonality of the construction business (with peaks in the summer months and a reduced activity in the winter months) cement demand follows comparable trends in most European countries.

In the sale of cement, transportation costs are a significant fraction of overall costs. This might suggest that the relevant geographical markets are more local. However, various 
decisions in cartel and merger cases (e.g., by the European Commission) confirmed that cement is also profitably delivered over longer distances. The Commission concluded in this respect that the "relevant market is therefore Europe, made up of an overlapping pattern of interdependent markets." "2 Given such interdependence, cartel agreements are often intended to allocate the overall market. As a consequence, a largely local pattern of deliveries cannot necessarily be attributed to economic constraints to long distance deliveries.

A general tendency of cartelization of cement markets can be explained by the presence of various factors that ease the implementation and stability of collusive agreements. For example, cement markets are typically characterized by a low number of cement producers, a relatively homogenous product, high market entry barriers and a rather inflexible production process. Interestingly, the assumed vulnerability for cartelization is not only supported by theoretical arguments but also reflected in the cartel enforcement record. In addition to the detected German cement cartel characterized in the following section, cement cartels have been identified and punished on the European level (e.g. European Commission, 1994) ${ }^{3}$ and on the national level, such as in Norway, Sweden, France, Poland, India or the United States of America to name only a few.

\subsection{The German cement cartel ${ }^{4}$}

In summer 2002, the German Federal Cartel Office (FCO) announced the alleged existence of a hardcore cartel in the German cement market. In the course of the investigation, it was found that a large number of German cement producers divided up the German market by a quota system at least since the early 1990s. Following its detailed investigation, the FCO found substantial supra-competitive proceeds due to elevated cement prices and imposed overall fines of about EUR 702 million with EUR 606 million referring to the six largest German cement producers Dyckerhoff AG, HeidelbergCement AG, Lafarge Zement GmbH, Readymix AG, Schwenk Zement KG und Holcim (Deutschland) AG.

The existence of the cartel was disclosed to the FCO under the German leniency program by the cartel member Readymix AG. The Higher Regional Court in Düsseldorf confirmed the illegal cartel agreements in its decision of 26 June 2009, however, reduced the fine level to a sum of EUR 329 million due to partly insufficient data. Fines totaling EUR 70 million

\footnotetext{
2 European Commission (1994), Commission imposes fines on a cement producers' cartel, Press release on 30 November 1994, available at http://europa.eu/rapid/pressReleasesAction.do?reference= IP/94/1108\&format= HTML\&aged=1\&language=EN\&guiLanguage=en (last accessed on 12 May 2012).

3 See European Commission decision of Cembureau.

4 This section largely follows Friederiszick and Röller (2010).
} 
became effective prior to the decision of the Higher Regional Court, because some cartel members did not appeal the decisions relating to those fines.

The proved existence of the cartel suggests that customers paid elevated prices for cement and were therefore harmed substantially. This assumption is supported by the substantial drop in the public price index for cement shown in Figure 2.

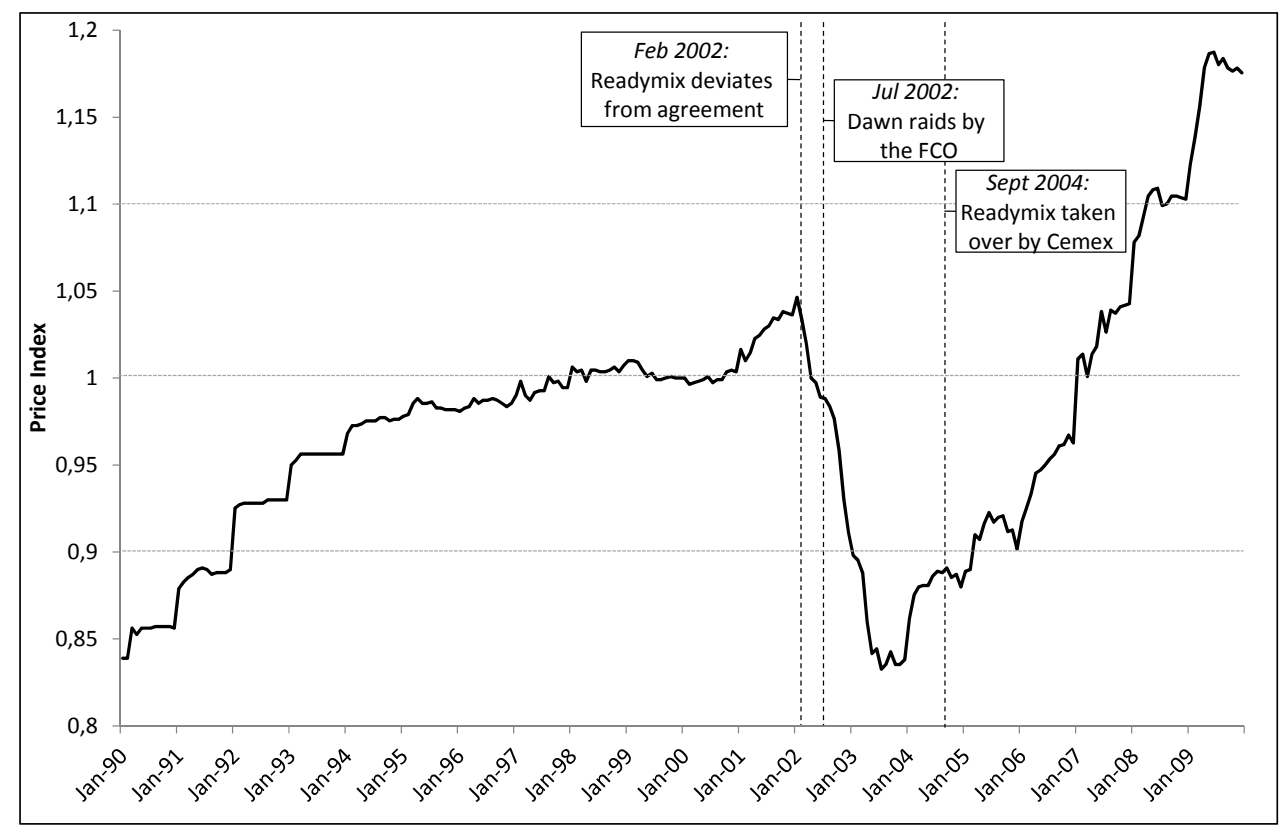

Figure 2: The public price index for cement from January 1990 to December 2009 Source: Own graph following Friederiszick and Röller (2010), p. 599

In addition to the general development of the public cement price index from January 1990 to December 2009, Figure 2 also marks key stages of the detection and prosecution of the cement cartel. The first indication of the cartel breakdown must be seen in the announcement of Readymix (in November 2001) to start replacing deliveries of other cartel members to its subsidiary concrete producers downstream with its own cement. The implementation of this announcement in February 2002 led to an increase in the (agreed) quotas for Readymix and was therefore interpreted as deviation from the agreement by the other cartel members. The official investigation of the alleged cement cartel started on 4 July 2002 with dawn raids by the FCO on the premises of 30 cement companies in Germany. ${ }^{5}$

During the hearings before the Higher Regional Court, it was heavily discussed how the substantial drop in the price index after the disclosure of the cartel must be interpreted. Although a price drop as such is naturally expected after a cartel breakdown, it was argued by the defendants that the price drop was partly caused by a price war, i.e., the observed bottom

Source: Press release of the German Federal Cartel Office on 8 July 2002, 'Searches conducted in companies in the cement sector' available at www.bundeskartellamt.de/wEnglisch/News/Archiv/ArchivNews2002/ 2002_07_08.php (last accessed on 12 May 2012). 
price cannot be interpreted as the competitive level but a level below that. Eventually, the court identified the acquisition of cartel breaker Readymix by Cemex as crucial event for the derivation of the but-for price, partly because the cement price index increased substantially in the aftermath of this event. ${ }^{6}$

\section{Estimating the price overcharge of the German cement cartel}

In this section, we use publicly available data to estimate the price overcharge of the German cement cartel. In particular, we apply two different comparator-based methods: the 'beforeand-after-approach' and the 'difference-in-difference approach'. We use price index data continuously collected by the German Federal Statistical Office (FSO). Major German cement producers are approached with a questionnaire and asked to provide overview information (including prices, quantities and qualities) on one representative CEM I sale activity close to the date of data collection (which is the $15^{\text {th }}$ of a month). As this data collection approach is highly standardized and used across a larger number of (cartelized and non-cartelized) firms, it offers possibilities for strategic behavior, e.g., with respect to the choice of the invoice handed over by the addressed firms to the FSO.

\subsection{The 'before-and-after' approach}

A prominent comparator-based approach refers to the analysis of price time series. Based on the brief characterization of the general concept in Section 2.1.1 above, we will apply an 'after' approach in the following.

\subsubsection{Basic econometric approach}

In the basic econometric approach, we take the cartel period - identified during the public enforcement trial - as given and further assume that the end of the cartel led to an immediate transition to the competitive price. We further assume that the price-determining variables are identical during and after the cartel leaving the cartel agreement as the only difference between both periods. We therefore define the following regression equation:

$$
p_{t}^{C}=\alpha+\beta_{\text {cart }} D_{\text {cart }}+\beta_{L} p_{t}^{L}+\beta_{E} p_{t}^{E}+\beta_{\text {Lig }} p_{t}^{\text {Lig }}+\beta_{\text {cprod }} \text { cprod }_{t}+\beta_{t} t+\varepsilon_{t}
$$

The cement price index at time $\mathrm{t}\left(p_{t}{ }^{C}\right)$ is determined by the constant term $\alpha$ and the following cost- or demand-related variables which vary over time. With respect to cost determinants, we include the price index for lime $\left(p_{t}{ }^{L}\right)$, the price index for electricity $\left(p_{t}{ }^{E}\right)$ and the price index for lignite $\left(p_{t}^{\text {Lig }}\right)$. The demand side is represented through the inclusion of the index for

It is important to note that the decision of the Higher Regional Court refers to public enforcement only (following criminal law standards), i.e., its decisions are not binding for the ongoing private enforcement lawsuit (following civil law standards). 
cement production $\left(\operatorname{cprod}_{t}\right)$. In order to estimate the effect of the cartel, we include the dummy variable $D_{\text {cart }}$ in the regression equation. The corresponding coefficient $\beta_{\text {cart }}$ shows the difference of the price index between the cartel period and the non-cartel period. Finally, $t$ is a time trend variable and $\varepsilon_{t}$ is the error term. Table 2 below shows the results of a simple OLS regression based on data from January 1995 to December 2009.

Table 2: Regression Results (OLS)

\begin{tabular}{l|clc}
\hline Variable & Coefficient & Sign. Level & (Std. Error) \\
\hline Cartel Period & 0.188 & $* * *$ & $(0.020)$ \\
Price Index Lime & 1.224 & $* * *$ & $(0.133)$ \\
Price Index Electricity & 0.047 & & $(0.073)$ \\
Price Index Lignite & 0.612 & $* * *$ & $(0.150)$ \\
Index Cement Production & 0.020 & $*$ & $(0.011)$ \\
Trend & 0.001 & $* * *$ & $(0.000)$ \\
Constant & -0.356 & $* * *$ & $(0.073)$ \\
\hline Number of Observations & \multicolumn{4}{|c}{180} \\
$\mathrm{~F}(6,173)$ & \multicolumn{4}{|c}{$0.72 .54 * *$} \\
$\mathrm{R}^{2}$ & \multicolumn{4}{|c}{0.72} \\
\hline
\end{tabular}

Remarks: Significance Level: $* * *<0.01, * *<0.05, *<0.1 ;$ Heteroscedasticity-consistent standard errors in parentheses.

Source: Federal Statistical Office, BDZ, Own Calculations.

The table shows the estimation results for the case of the logarithm of the respective variables. It is revealed that the price difference between the cartel period and the non-cartel period (i.e., the price overcharge) is $\exp (0.188)-1=20.7 \%$. If we assume an average cement price of EUR 55 per ton, the price overcharge can be calculated to be EUR 11.38 per ton. With respect to the relationship between the cement price and the lime price, the regression results reveal that a $1 \%$ increase in the price of lime leads to a $1.224 \%$ increase in the price of cement. For the lignite price index, we find that a price increase of $1 \%$ leads to an increase of the cement price of $0.612 \%$. Interestingly, we find no statistically significant effect for the price of electricity on the price for cement. This is surprising given the high energy-intensity of the cement production process. Last but not least, we find a positive relationship between the production of cement and the price of cement. This result is understandable given the fact that cement is not easy to store and therefore largely produced on demand.

\subsubsection{Extensions of the basic econometric approach}

In the following two sub-sections we extend the basic econometric approach in two separate ways. First, we introduce an instrumental variable to take the usual interdependence between 
prices and quantities into account. Second, we assume a transition period from the cartel to the non-cartel period.

\subsubsection{Introduction of an instrumental variable}

A key problem ignored by the basic econometric approach is the interdependence of cement price and cement demand. In a non-monopolistic market a mutual reaction can be expected as, on the one hand, an increase in the demand leads to an increase in the willingness to pay. Producers are therefore able to charge a higher price per unit. On the other hand, a decrease in price, e.g., due to an improved production technology, leads to an increase in demand for the respective product. As a consequence, interdependencies between price and demand exist which cannot be disentangled and therefore cause difficulties in an investigation of the impact of cement demand on cement price. From an econometric perspective, ignoring the interdependence can cause serious consequences in the form of biased coefficients and therefore possibly erroneous estimates of the impact of cement demand on cement price.

In order to solve the endogeneity issue, we have to create a relationship between independent and dependent variables. In the following, we will instrument cement demand. A key question in this respect is which factors influence cement demand. As soon as we can identify one or more factors which influence cement demand but not (directly) the cement price, these factors can be seen as valid instruments.

Cement is largely used as an input good in the construction business. As the cement costs typically account for only a small fraction of entire construction costs (e.g., around $3 \%$ for the construction of a single-family home), it is reasonable to assume that the construction decision does not depend on the price for cement. It can therefore be concluded that the demand for cement depends on construction activity, however, no (significant) effect of the cement price on construction activity can be assumed.

In the following extended estimation approach, we refrain from including cement production itself as independent variable but instrument cement production by several new variables which reflect construction activity. We start off by determining the influence of different construction variables on cement production and continue by deriving a separate value of cement production for every point in time. As the estimated (derived) value does not represent the actual cement production any more, it can be included into the estimation equation of the basic approach described above. Technically, in a first step, we explain cement production by the following model: 


$$
\begin{aligned}
\text { cprod }_{t}= & \alpha^{n f}+\beta_{D C}^{n f} D C_{t}+\beta_{I S C}^{n f} I S C_{t}+\beta_{S C P L B}^{n f} S C P L B_{t}+\beta_{S C N P B}^{n f} S C N P B_{t}+\beta_{R C}^{n f} R C_{t} \\
& +\beta_{I U C}^{n f} I U C_{t}+\beta_{U C P B}^{n f} U C P L B_{t} \\
& +\beta_{\text {cart }}^{n f} D_{\text {cart }}+\beta_{L}^{n f} p_{t}^{L}+\beta_{E}^{n f} p_{t}^{E}+\beta_{\text {Lig }}^{n f} p_{t}^{L i g}+\beta_{t} t+\varepsilon_{t}^{n f}
\end{aligned}
$$

The first two lines in equation (2) measure the impact of the so-called instruments. We include the following seven variables: Domestic Construction $(D C)$, Industrial Surface Construction (ISC), Surface Construction for Public Law Bodies (SCPLB), Surface Construction for Non-Profit Bodies $(S C N P B)$, Road Construction $(R C)$, Industrial Underground Construction (IUC) and Underground Construction for Public Law Bodies $(U C P L B)$. In addition, the remaining variables are also used as further instruments in the second step of the analysis. In our case, these variables are taken from the basic model estimated above. The estimated value of the index of cement production is inserted into the basic model derived above:

$$
p_{t}^{Z}=\alpha^{p}+\beta_{\text {cart }}^{p} D_{\text {cart }}+\beta_{L}^{p} p_{t}^{L}+\beta_{E}^{p} p_{t}^{E}+\beta_{\text {Lig }}^{p} p_{t}^{\text {Lig }}+\beta_{\text {cprod }}^{p} \widehat{\operatorname{cprod}}_{t}+\beta_{t} t+\varepsilon_{t}^{p}
$$

\begin{tabular}{|c|c|c|c|}
\hline Variable & Coefficient & Sign. Level & (Std. Error) \\
\hline Cartel Period & 0.185 & $* * *$ & $(0.020)$ \\
\hline Price Index Lime & 1.234 & $* * *$ & $(0.132)$ \\
\hline Price Index Electricity & 0.038 & & $(0.074)$ \\
\hline Price Index Lignite & 0.631 & $* * *$ & $(0.155)$ \\
\hline Index Cement Production (instrumented) & 0.028 & $* *$ & $(0.012)$ \\
\hline Trend & 0.001 & $* * *$ & $(0.000)$ \\
\hline Constant & -0.349 & $* * *$ & $(0.074)$ \\
\hline First Level & \\
\hline Number of Observations & \multicolumn{3}{|c|}{180} \\
\hline $\mathrm{F}(12,167)$ & \multicolumn{3}{|c|}{$63.80 * * *$} \\
\hline (adj.) $R^{2}$ & \multicolumn{3}{|c|}{0.81} \\
\hline Second Level & \\
\hline Number of Observations & \multicolumn{3}{|c|}{180} \\
\hline $\mathrm{F}(6,173)$ & \multicolumn{3}{|c|}{$154.05 * * *$} \\
\hline $\mathrm{R}^{2}$ & \multicolumn{3}{|c|}{0.72} \\
\hline
\end{tabular}

The results of the respective second level estimations are shown in Table 3.

\section{Table 3: Regression Analysis (Instrument Variable Estimation - Second Level Coefficients)}

Remarks: Significance Level: $* * *<0.01, * *<0.05, *<0.1 ;$ Heteroscedasticity-consistent standard errors in parentheses.

Source: Federal Statistical Office, BDZ, Own Calculations.

Comparing the results of the basic regression approach with the results of the extended regression approach reveals that the coefficients are very similar with respect to both direction and size. In particular, the price overcharge remains largely unaffected by the inclusion of the 
instrumented variable with a value of $\exp (0.185)-1=20.32 \%$. Again, we find no statistically significant effect for the price of electricity on the price for cement.

\subsubsection{Modeling a transition period from the cartel to the non-cartel state}

The model approaches so far assumed that the cartel period is immediately followed by the non-cartel period. However, for several reasons, it is reasonable to assume that the breakdown of a cartel agreement is followed by a transition period from the cartel to the non-cartel state. First, even after cartel detection, forms of tacit collusion might still have some impact leading to a lagged price decline down to the competitive level. Second, in many upstream product markets, medium- and long-term contracts may lead to certain price persistence even after the cartel breakdown. Third, price rigidities can play a more general role, e.g. in the sense that cost changes are not reflected immediately in respective price changes.

The likely existence of a transition period from the cartel to the non-cartel period demands an econometric approach that explicitly takes this period into account. As the transition period is caused by the cartel agreement, the smaller but still elevated prices in the transition period must be included into the price overcharge estimation and the subsequent calculation of damages. As the actual transition process is not known, an econometric model has to consider simplified assumptions on the transition period. In particular, the following three questions must be assessed. First, up to which point in time did the high cartel prices prevail after the cartel breakdown? Second, over which period does the transition from the cartel to the noncartel state take place? Third, which functional form does the transition process follow?

One possibility for the modeling of the price development in the transition period is to assume a linear price development by introducing an indicator variable with the value ' 1 ' during the cartel and the transition period and the value ' 0 ' otherwise. Although indicator variables by definition have two specifications, a graduation can be implemented quite easily. A value of ' 1 ' of the indicator variable basically means that the price at this particular point in time contains the full price overcharge of the cartel. If the indicator variable reaches a value of ' 0.5 ' after the breakdown of the cartel, the respective price still contains half of the price overcharge of the cartel and so on. Figure 3 sketches two examples of transition periods and their impact on the respective price overcharge estimations. 
Linear Transition Period

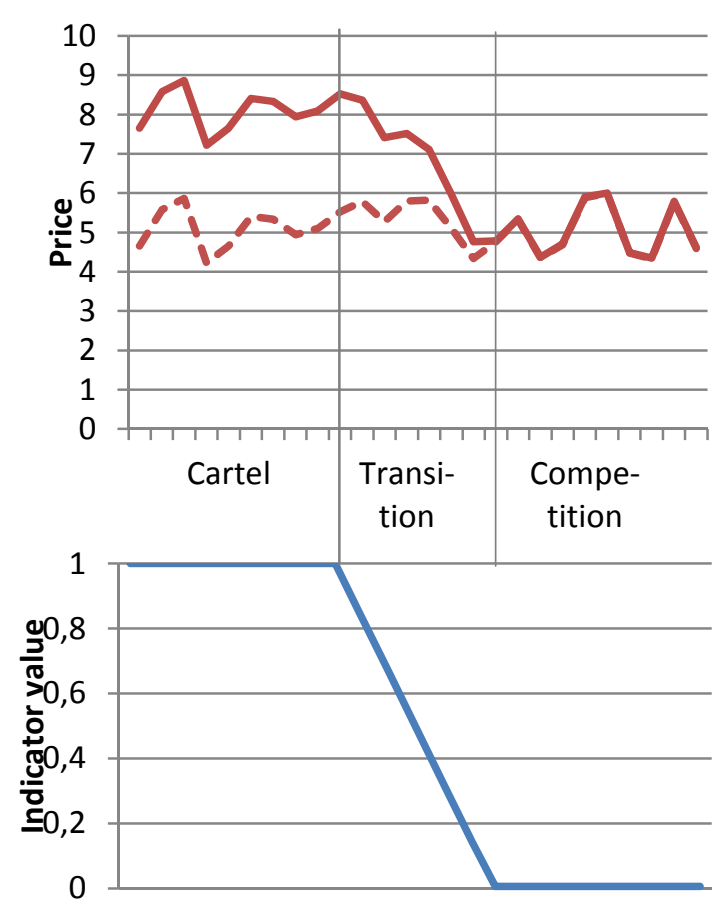

No Transition Period
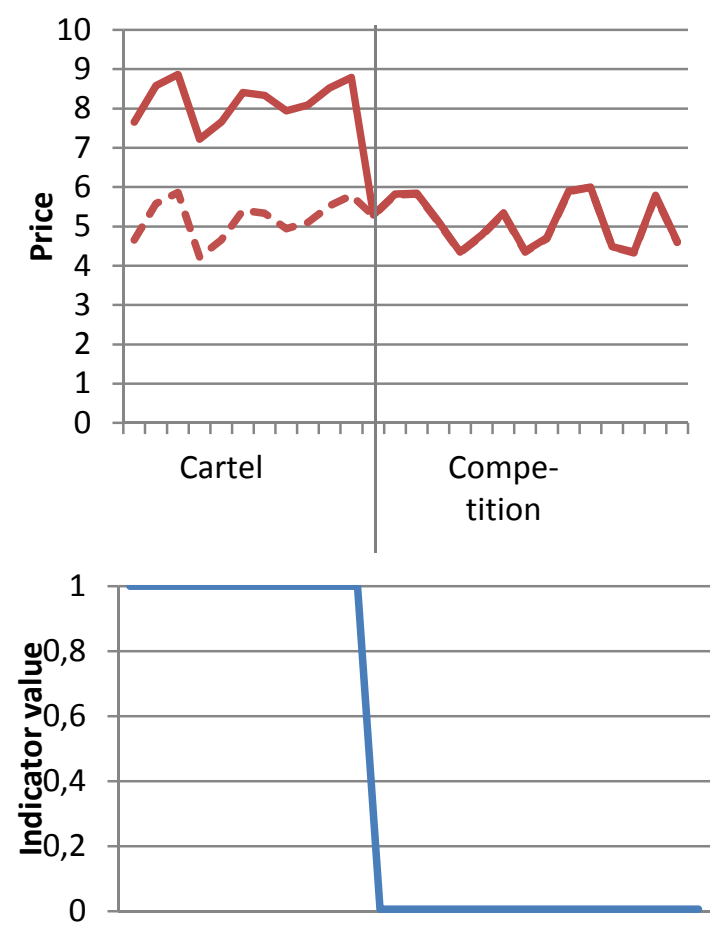

Figure 3: Design of the Indicator Variable ,Cartel Period‘

Source: Own Figure

Instead of an introduction of a continuous indicator variable, it would alternatively be possible to introduce an additional indicator variable which has a value of ' 1 ' in the transition period and a value of ' 0 ' otherwise. Although such a solution does not assume a specific functional form, it still allows accounting of the transition period.

Based on this brief general discussion of the relevance of considering the transition, we continue by comparing the effect of different transition periods on the price overcharge estimate. In the following, we apply the extended econometric model (following the instrument variable approach) and include the transition period in the estimation of the price overcharge. In particular, we differentiate between three transition periods: January to April 2002 (columns (1) and (2) in Table 4), January to June 2002 (columns (3) and (4)) and January to July (columns (5) and (6)). As reference point, column (0) in Table 4 repeats the results of the estimation of the extended econometric model above. Models (1), (3) and (5) use an indicator variable to mark the transition period (which is treated as part of the cartel period). In models (2), (4) and (6), a continuous transition is assumed, i.e. in column (2), the indicator variable has a value of 0.8 in January, a value of 0.6 in February and so on. 


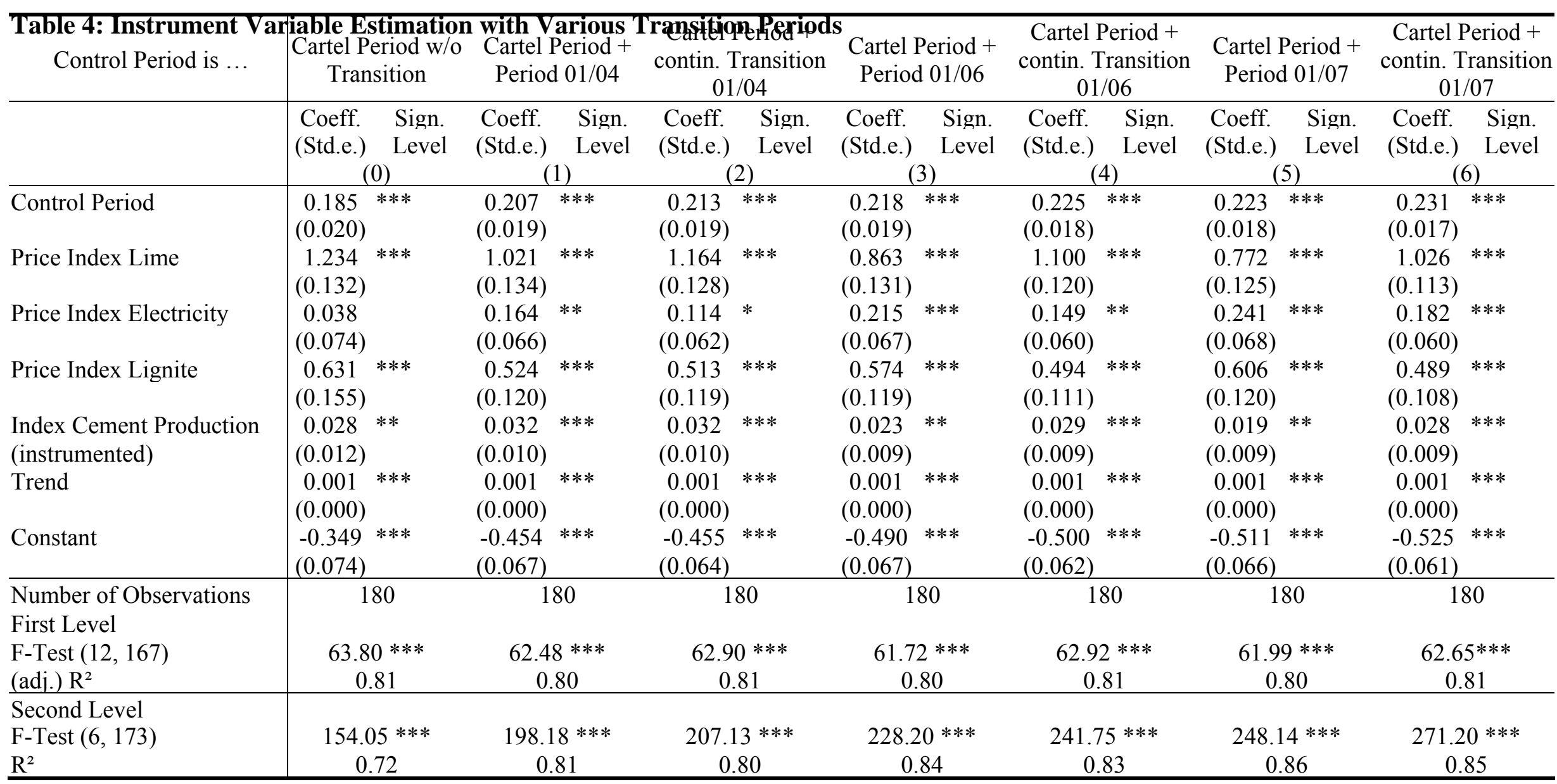

Remarks: Significance Level: $* * * 0.01, * *<0.05, *<0.1 ;$ Heteroscedasticity-consistent standard errors in parentheses.

Source: Federal Statistical Office, BDZ, Own Calculations. 
A comparison of the coefficients in the different columns in Table 4 reveals that an extension of the cartel period through the introduction of transition periods leads to significant increases in the estimated price overcharges (models (1), (3) and (5)). For example, if we include the transition period until April 2002 into the cartel period, we receive a price overcharge of $23.00 \%(=\exp (0.207)-1)$ in model 1 compared to a price overcharge of $20.32 \%$ $(=\exp (0.185)-1)$ in the model without any transition period (model $(0))$.

If instead a linear reduction of the indicator variable over the transition period is assumed (models (2), (4) and (6)), the respective coefficient increases further $(23.7 \%, 25.2 \%$ and $26.0 \%$ ). This can be explained by the fact that within the transition period, the higher values of the price index close to the cartel period are allocated with a larger share to the non-cartel period. For the cement market with its partly medium- and long-term supply contracts, it is reasonable to assume that a linear reduction of the indicator variable provides a better fit than a "0-1" dummy variable can do.

\subsection{The ,difference-in-differences' approach}

In this section, we apply a second model approach to estimate the price overcharge of the German cement cartel: the so-called 'difference-in-differences' (DiD) approach. As described in Section 2.1.2 above, the DiD approach combines the 'before-and-after' approach with a geographic or product-related comparator approach. The approach also takes into account that not the entire price difference between the cartel period and the post-cartel period must be related to the cartel agreement but can also be influenced by other factors such as changes in various cost drivers. Ignoring the possible impact of these additional factors might lead to under- or overestimations of the price overcharge. The DiD approach considers these factors by assuming that these cost drivers do not differ across different geographical comparator markets. Technically, we implement the DiD approach by estimating the following equation:

$$
\begin{aligned}
p_{m t}^{C}= & \beta_{0}+\beta_{1} K_{t}+\beta_{2} D_{m}+\beta_{3} D_{m} * K_{t}+\beta_{4} p_{m t}^{E} \\
& +\beta_{5} \text { Year }_{t}+\beta_{6} Q 2_{t}+\beta_{7} Q 3_{t}+\beta_{8} Q 4_{t}+\varepsilon_{m t}
\end{aligned}
$$

with $K_{t}$ being the indicator variable which has a value of , $1^{\text {' }}$ during the cartel period and , 0 ' otherwise. $D_{m}$ is the indicator variable which has a value of , $1^{\text {' }}$ in the cartelized market $m$ (in our case Germany) and , $0^{‘}$ in other markets (other countries in our case). The DiD-estimator of the price overcharge is coefficient $\beta_{3}$ of the interaction term $D_{m}{ }^{*} K_{t}$. As the available price data in all cases are indices, we again use the logarithm of the respective index values, i.e., we investigate the percentage increase of the 'but-for' price (which can be derived by $\left.\exp \left(\beta_{3}\right)-1\right)$.

As control variables, we include the logarithm of the respective energy price indices $\left(p_{m t}^{E}\right)$, a trend variable $\left(\right.$ Year $\left._{t}\right)$ and seasonal effects by introducing quarter dummies $\left(Q 2_{t}{ }^{-} Q 4_{t}\right)$. As the 
first quarter acts as reference period, the coefficients $\beta_{6}$ to $\beta_{8}$ measure the percentage difference of the cement price as compared to the first quarter.

As geographical comparators, the following countries are used: Spain, France, the UK and Poland. ${ }^{7}$ Figure 4 below plots the respective national cement price indices for the period from 1991 to 2008.

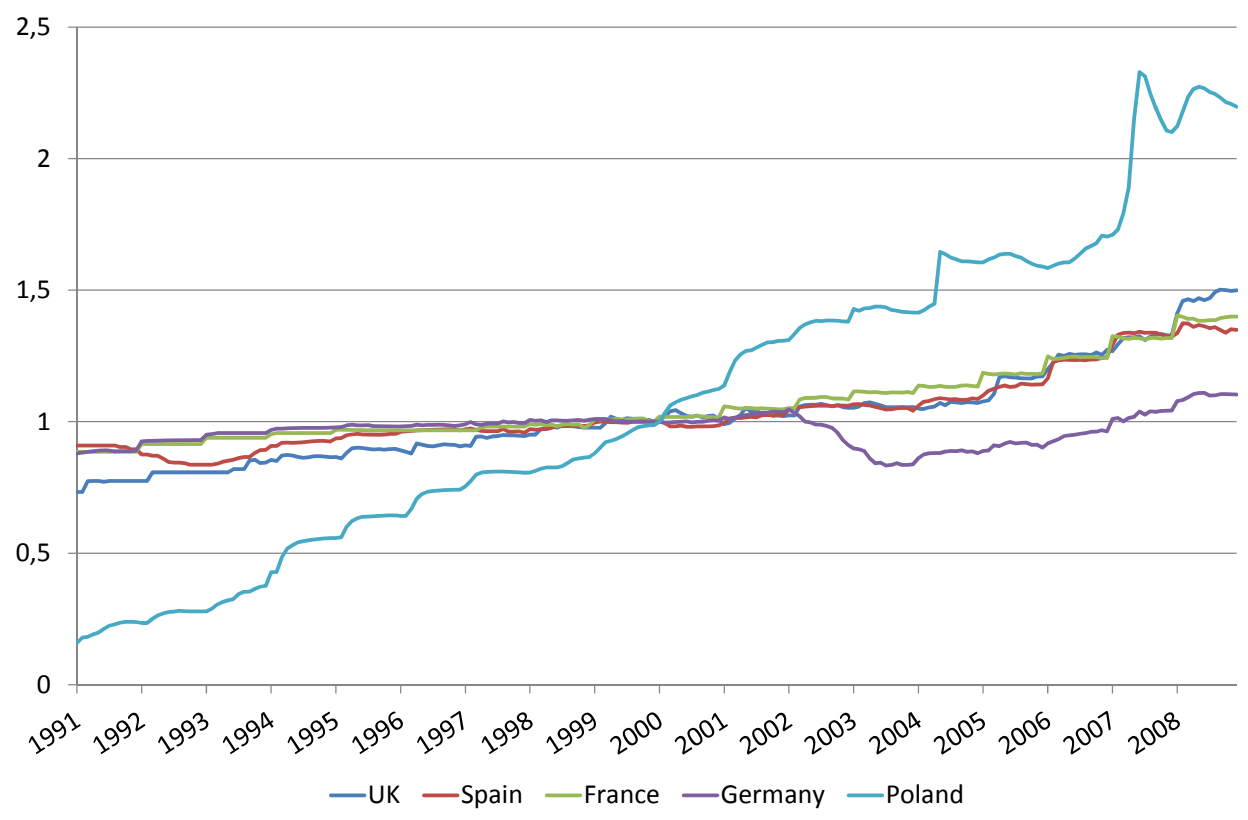

Remark: January $2000=1$

Figure 4: National Cement Price Indices from 1991 to 2008

Sources: Statistical Offices of the Respective Countries; Own Calculations.

As shown in Figure 4, all national cement price indices show an increasing trend for the observation period. However, while the national indices of the UK, Spain, France and Germany are moving closely together from 1991 to 2002, the price reduction after the breakdown of the German cartel led to a substantial drop in the cement price index for Germany. The price index for Poland follows a rather different trend, partly triggered by the transition to a social market economy, the existence of a cement cartel (at least between 1998 and 2006) and acquisition activities of large cement producers in the Polish market after liberalization.

As argued above, energy prices are expected to be an important driver of cement prices. For an application of a $\mathrm{DiD}$ approach, it is therefore necessary to collect information on the energy price level in the respective countries. The national energy price indices from 1991 to 2004 are plotted in Figure 5.

\footnotetext{
The chosen comparator countries might not be that suitable as cement cartels might have existed in those countries as well during the observation period. For example, the Polish competition authority recently fined a cement cartel that was operating in Poland at least from 1998 to 2006.
} 


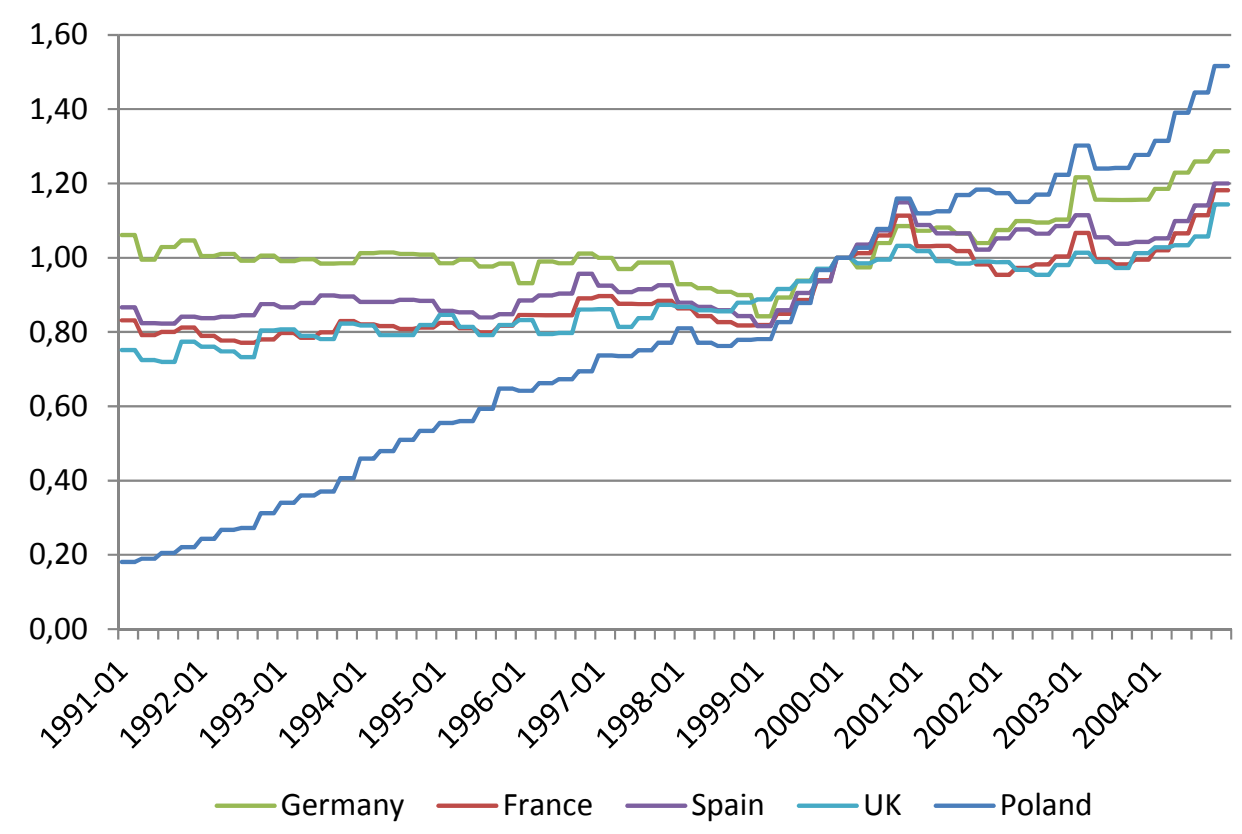

Remark: January 2000=1

Figure 5: National Energy Price Indices from 1991 to 2004

Sources: OECD/IEA; Own Calculations.

Poland again shows a rather special development of its energy price index basically due to the transition period described above. The national energy price indices of the other countries in the sample show similar and rather constant developments in the 1990s but experience substantial increases since 2002 . Table 5 finally provides the descriptive statistics of all model variables used in the DiD estimation.

Table 5: Descriptive Statistics for the 'Difference-in-Differences' Model

\begin{tabular}{l|cc|cc}
\hline \multirow{2}{*}{ Country } & \multicolumn{2}{|c|}{ Cement Price Index } & \multicolumn{2}{c}{ Energy Price Index } \\
Mean & Std. Dev. & Mean & Std. Dev. \\
\hline & & & & \\
Germany & 0.962 & 0.053 & 1.029 & 0.091 \\
Spain & 0.971 & 0.068 & 0.947 & 0.104 \\
France & 0.981 & 0.069 & 0.901 & 0.106 \\
United Kingdom & 0.936 & 0.098 & 0.887 & 0.103 \\
Poland & 0.853 & 0.428 & 0.790 & 0.373 \\
\hline
\end{tabular}

Remark: Period 1991-2004

Sources: Cement Price Indices: Statistical Offices of the Respective Countries; Energy Price Indices: OECD/IEA; Own Calculations.

As shown in the table, the standard deviation of both the cement price index and the energy price index is substantially higher for Poland than for the other countries in the sample. This observation can largely be explained by a much more pronounced increase in the cement prices in Poland compared to the other countries between 1991 and 2004.

In the following, we estimate equation (4) with three separate techniques. The so-called pooled model applies an OLS method and corrects the standard errors for a possible 
correlation within a country (cluster-robust). In contrast, panel data methods (random-effects or fixed-effects) are able to consider an additional unobservable, time invariant but individual effect (here countries) and therefore increase the quality of the estimation. The estimation results for all three techniques are shown in Table 6.

Table 6: Regression Results (,Difference-in-differences')

\begin{tabular}{|c|c|c|c|c|c|c|}
\hline \multirow[b]{2}{*}{ Variables } & \multicolumn{2}{|c|}{ Pooled Model (OLS) } & \multicolumn{2}{|c|}{ Random-effects } & \multicolumn{2}{|c|}{ Fixed-effects } \\
\hline & $\begin{array}{c}\text { Coeffi- } \\
\text { cient }\end{array}$ & $\begin{array}{l}\text { Std. } \\
\text { Err. }\end{array}$ & $\begin{array}{c}\text { Coeffi- } \\
\text { cient }\end{array}$ & $\begin{array}{l}\text { Std. } \\
\text { Err. }\end{array}$ & $\begin{array}{c}\text { Coeffi- } \\
\text { cient }\end{array}$ & $\begin{array}{l}\text { Std. } \\
\text { Err. }\end{array}$ \\
\hline Cartel Period & 0.017 & $(0.024)$ & 0.017 & $(0.025)$ & 0.017 & $(0.025)$ \\
\hline Germany & $-0.311 * * *$ & $(0.030)$ & $-0.312 * * *$ & $(0.030)$ & & \\
\hline Cartel & $0.235 * * *$ & $(0.022)$ & $0.233 * * *$ & $(0.021)$ & $0.233 * * *$ & $(0.021)$ \\
\hline $\begin{array}{l}\text { Period*Germany } \\
\text { log(Energy Price } \\
\text { Index })\end{array}$ & $1.015 * * *$ & $(0.059)$ & $1.024 * * *$ & $(0.067)$ & $1.025 * * *$ & $(0.068)$ \\
\hline Year & 0.001 & $(0.005)$ & 0.000 & $(0.005)$ & 0.000 & $(0.005)$ \\
\hline Second Quarter & 0.023 & $(0.011)$ & $0.023 * *$ & $(0.011)$ & 0.023 & $(0.011)$ \\
\hline Third Quarter & 0.018 & $(0.013)$ & 0.018 & $(0.013)$ & 0.018 & $(0.013)$ \\
\hline Fourth Quarter & $-0.012 *$ & $(0.004)$ & $-0.012 * * *$ & $(0.004)$ & $-0.012 * *$ & $(0.004)$ \\
\hline Constant & -0.995 & $(9.631)$ & -0.105 & (10.377) & -0.134 & $(10.402)$ \\
\hline Number of observ. & 840 & & 840 & & 840 & \\
\hline Countries & 5 & & 5 & & 5 & \\
\hline $\mathrm{R}^{2}$ (within) & & & 0.946 & & 0.946 & \\
\hline $\mathrm{R}^{2}$ (between) & & & 0.971 & & 0.589 & \\
\hline $\mathrm{R}^{2} / \mathrm{R}^{2}$ (overall) & 0.949 & & 0.949 & & 0.821 & \\
\hline
\end{tabular}

Remarks: Significance Level: $* * *<0.01, * *<0.05, *<0.1 ;$ Heteroscedasticity-consistent and cluster-robust standard errors in parentheses.

Sources: Statistical Offices of the Respective Countries and OECD/IEA; Own Calculations.

As shown in Table 6, especially energy costs are now found to be an important determinant of the cement price. Elasticities vary from 1.015 to 1.025 depending on the model approach; however, the Wald test reveals that these values are statistically not different from each other. The coefficient of the Germany-dummy $\left(\beta_{2}\right)$ is statistically significant and clearly negative indicating that cement prices in Germany in the period from 1991-2004 increased less than in the comparator countries. This fact was already shown in Figure 4 above which plotted the cement price indices of the respective countries in the sample. The estimated price overcharge is shown in the third (bold) line in Table 6. For the pooled model, a price overcharge of $\exp (0.235)-1=26.5 \%$ is found which is slightly reduced for the panel data estimations $((0.233)-1=26.2 \%)$. The decision whether the random-effects or the fixed-effects method provides the better fit can be made by conducting the Hausman test. In our case, the results of the Hausman test show no systematic differences between both estimations suggesting that the 'random-effect' estimation should be favored due to its better efficiency characteristic. 
The identified differences between the price overcharge estimates of the 'before-and-after' approach (20.3\% to $26.0 \%)$ and the 'difference-in-differences' approach (26.2\% to $26.5 \%)$ demand a brief discussion of possible explanations. First, both model approaches use data sets of different lengths. While the before-and-after estimates refer to data from 1995 to 2009, data limitations only allowed us to use data from 1991 to 2004 for the DiD approach. As a consequence, price overcharges are not fully comparable. Second, the larger value of the DiD estimations can be explained by the fact that especially in the post-cartel period substantial increases in the cement price have been observed in the comparator countries driving the (DC) term of the DiD approach negative. Third, it cannot be ruled out that cement cartels were operating in several other comparator countries as well. Such parallel cartels would also be likely to lead to biased estimates.

\section{Conclusion}

There is no question that the fight against hardcore cartels is ranked high on the agenda of antitrust authorities these days. For example, the former European Commissioner responsible for competition policy, Neelie Kroes ${ }^{8}$, frequently stated that one key aim of her work was not only to "... merely destabilize cartels. I want to tear the ground from under them". The first cartel actions taken by her successor, Joaquín Almunia", left no doubt that "[t]he Commission will continue its relentless fight against cartels".

The overall strategy of the European Commission to enforce anti-cartel rules can be subdivided into two different strands. On the one hand, the Commission fosters public enforcement, e.g., through the introduction of a leniency program, increased cooperation between different national antitrust authorities or the extension of the fine spectrum for antitrust infringements. On the other hand, the Commission has started to strengthen the private enforcement of antitrust laws, e.g., through the launching of a large project on the development of a legal framework that allows victims of EU antitrust infringements to obtain compensation. As the size of the compensation - in the case of hardcore cartels - depends on the demanded quantities of the cartelized product and the cartel-induced increase in price, it becomes apparent that especially the robust estimation of the so-called price overcharge is crucial for a coherent and welfare-improving private enforcement of anti-cartel rules.

Against this background, we use publicly available price data from a German cement cartel to estimate the achieved price overcharge. In particular, we apply two different comparatorbased approaches - a 'before-and-after' approach and a 'difference-in-differences' approach -

\footnotetext{
Kroes, N., Tackling Cartels - A Never-Ending Task, European Commission SPEECH/09/454, 8 October 2009, Brussels.

9 Almunia, J., First Cartel Decision under Settlement Procedure - Introductory Remarks, European Commission SPEECH/10/247, 19 May 2010, Brussels.
} 
and especially study the impact of various assumptions on the transition period from the cartel period to the non-cartel period on the estimated price overcharge. We find that the cartel managed to implement price increases in a range from $20.3 \%$ (extended approach with instrumented cement demand) to $20.7 \%$ (basic approach) for the 'before-and-after' method and from $26.2 \%$ (pooled OLS) to $26.5 \%$ (random-effects) for the 'difference-in-differences' method. For the (extended) 'before-and-after' approach, we further show that various assumptions on the transition period from the cartel period to the non-cartel period have a significant impact on the estimated price overcharge. While the absence of a transition period leads to a price overcharge of $20.3 \%$, a continuous transition period from January to July 2002 arrives at an overcharge estimate of $26.0 \%$. It therefore becomes apparent that the choice of the transition period has a substantial impact on the estimated price overcharge and should therefore become a compulsory step in cartel damage estimations.

Although the paper investigates the impact of one particular cartel in one particular industry in one particular country, our results point towards several fruitful future research areas. First, the co-existence of public and private enforcement activities raises the demand for studies which investigate the interrelationships between both enforcement types. Thoughtful answers to the question whether the EU might be confronted with a situation of socially inefficient over-enforcement - as soon as the already existing public enforcement regime is complemented by more and more private initiatives to enforce anti-cartel laws will be particularly important for the design of a coherent and efficient general enforcement regime.

Second, within the system of private enforcement, our analysis showed that different methods and models will typically lead to different overcharges (and therefore different damage estimates). In court, this constellation will often cause a resource-intensive battle between defendants and plaintiffs for the true damage estimate. In an attempt to improve this complex situation, the UK Department for Business Innovation \& Skills (2012) proposed the introduction of a rebuttable presumption of loss in cartel cases: "This would be likely to take the form of a presumption that a cartel had affected prices by a fixed amount, such as $20 \% \ldots$ If no economic evidence was presented by either side, the damages award would be based on this assumption. The presumption would be rebuttable by either the claimant or defendant; however, to do so they would have to present the necessary evidence ..." (Department for Business Innovation \& Skills (2012), p. 24). Although the proposal has clear advantages such as the promotion of the incentives for harmed parties to start litigation against cartelists or the shift of the burden of proof to the party most likely to possess the data necessary to calculate the true damages, it seems rather unlikely that such a rule will have a substantially negative 
effect on average litigation costs. The defendants will still provide evidence that the true damage is substantially below 20 percent and the plaintiffs are likely to respond with opposing empirical evidence.

Although it is indisputable that private antitrust enforcement in the European Union is still in its infancy - with substantial improvement potential yet to be realized - it becomes apparent that the final success will crucially depend on how close lawyers and economists are willing and able to work together. Lawyers could promote such a mutual learning process by becoming more open to economic analysis while economists are in demand to provide clear guidance to lawyers in the crucial aspects of the economics of damage estimations. In the coming years, it will be interesting to observe how well this interdisciplinary cooperation works and therefore how much the private enforcement of anti-cartel laws will contribute to the overall benefits of competition law and policy in the European Union. 


\section{References}

ABA Section of Antitrust Law (2010), Proving Antitrust Damages: Legal and Economic Issues, Second Edition, Washington D.C.

Brander, J.A. and T.W. Ross (2006), Estimating Damages from Price-Fixing. Canadian Class Action Review, Vol. 3(1), 335-369.

CEPS (Centre for European Policy Studies), EUR (Erasmus University Rotterdam) und LUISS (Luiss Guido Carli) (2007), Making Antitrust Damages Actions More Effective in the EU: Welfare Impact and Potential Scenarios, Report for the European Commission, Contract DG COMP/2006/A3/012.

Connor, J.M. (2008), Forensic Economics: An Introduction with Special Emphasis on Price Fixing, Journal of Competition Law and Economics 4, 31-59.

Connor, J.M. and Lande, R.H. (2008), 'Cartel Overcharges and Optimal Cartel Fines', chapter 88, pp. 2203-18, in S.W. Waller (ed.), Issues in Competition Law and Policy, Volume 3, ABA Section of Antitrust Law.

Connor, J.M. and R. Lande (2006), The Size of Cartel Overcharges, Antitrust Bulletin 51, 983-1022.

Davis, P. and E. Garcés (2010), Quantitative Techniques for Competition and Antitrust Analysis, Princeton.

De Coninck, R. (2010), Application of the Nonhorizontal Merger Guidelines, Antitrust Bulletin 55, 929-952.

Department for Business Innovation \& Skills (2012), Private Actions in Competition Law: A Consultation on Options for Reform, London.

European Commission (2011), Draft Guidance Paper - Quantifying Harm in Actions for Damages Based on Breaches of Article 101 or 102, Brussels.

European Commission (2008), White Paper on Damages Actions for Breach of the EC Antitrust Rules, COM (2008) 165, Brussels.

European Commission (2005), Green Paper - Damages Actions for Breach of the EC Antitrust Rules, COM (2005) 672, Brussels.

Friederiszick, H.W. and L.H. Röller (2010), Quantification of Harm in Damages Actions for Antitrust Infringements: Insights from German Cartel Cases. Journal of Competition Law and Economics 6, 595-618.

Harrington, J.E. (2004a), Post-Cartel Pricing during Litigation. Journal of Industrial Economics 52, 517-533.

Harrington, J.E. (2004b), Cartel Pricing Dynamics in the Presence of an Antitrust Authority. RAND Journal of Economics 35, 652-674. 
Hüschelrath, K., N. Leheyda, K. Müller, T. Veith (2012), Schadensermittlung und Schadensersatz bei Hardcore-Kartellen: Ökonomische Methoden und rechtlicher Rahmen, Baden-Baden.

Levenstein, M. and V. Suslow (2004), What Determines Cartel Success?, Working Paper, University of Michigan, Ann Arbor.

Nieberding, J.F. (2006), Estimating Overcharges in Antitrust Cases Using a Reduced-Form Approach: Methods and Issues, Journal of Applied Economics 9, 361-380.

OECD (2002), Fighting Hardcore Cartels: Harm, Effective Sanctions and Leniency Programmes, Paris.

Oxera (2009), Quantifying Antitrust Damages: Towards Non-binding Guidance for Courts, Study prepared for the European Commission.

Oxera (2008), Damages Actions: The European Commission White Paper, Agenda July 2008, Oxford.

Pepall, L., D. Richards, and G. Norman (2001), Industrial Organization: Contemporary Theory and Practice, Boston.

Smith, A. (1776), An Inquiry into the Nature and Causes of the Wealth of Nations, London.

Van Dijk, T. and F. Verboven (2008), Quantification of Damages, Chapter in Collins, Wayne Dale (Hrsg): Issues in Competition Law and Policy, ABA Publications in Antitrust.

Verboven, F. (2007), Quantification of Cartel Damages: Economic Framework and Empirical Methods, Presentation at NMa Conference on "Measuring the Economic Effects of Competition Law Enforcement".

Werden, G. (2003), The Effect of Antitrust Policy on Consumer Welfare: What Crandall and Winston Overlook, Economic Analysis Group Working Paper, Antitrust Division, Washington D.C. 